Chirurgia (2019) 114: 611-621

No. 5, September - October

Copyright@ Celsius

http://dx.doi.org/10.21614/chirurgia.114.5.611

\title{
Partial Adrenalectomy - Arguments for the Minimally Invasive Surgical Approach
}

\author{
Irina Balescu', Octavian Arnautu', Mugur Grasu², Corin Badiü ${ }^{3}$, Victor Tomulescu', Catalin Copaescu ${ }^{1,4}$ \\ 'Ponderas Academic Hospital Bucharest, Romania \\ ${ }^{2}$ Department of Radiology, Fundeni Clinical Institute, Bucharest, Romania \\ ${ }^{3}$ Department of Endocrinology, "C. I. Parhon" National Institute of Endocrinology, "Carol Davila" University of Medicine and Pharmacy, \\ Bucharest, Romania \\ 4"Grigore T Popa" University of Medicine and Pharmacy, Iași, Romania
}

Corresponding author:

Catalin Copaescu, MD PhD

Associated Professor of Surgery

Ponderas Academic Hospital

Nicolae Caramfil Street, no. 85 A

district 1, Bucharest, Romania

E-mail: catalin.copaescu@ponderas-ah.ro

\section{Abbreviations:}

PA - Partial Adrenalectomy;

LA - Laparoscopic Adrenalectomies;

MIS - Minimally Invasive Surgery;

LPA - Laparoscopic Partial

Adrenalectomy:

LUS - Laparoscopic Ultrasound;

ICG - Indocyanine Green Test;

MIS-PA - Minimally Invasive Surgery

Partial Adrenalectomies;

NIR - Near-Infrared Light;

ICG - Indocyanine Green;

POD - Postoperative Day;

RR - Relative Risk;

IVC - Inferior Vena Cava;

Received: 05.09.2019

Accepted: 10.10 .2019

\section{Rezumat}

Suprarenalectomia partială - argumente pentru chirurgia minimal invazivă

Introducere: suprarenalectomia parțială a fost efectuată pe scară din ce în ce mai largă în ultimele decade cu scopul de a diminua numărul pacienților ce ar putea deveni dependenți pe viață de substituția hormonală.

Metodă: între 2016 şi 2018 şapte pacienți au fost supuşi suprarenalectomiei parțiale minimal invazive în Ponderas Academic Hospital.

Rezultate: vârsta medie la momentul intervenției chirurgicale a fost de 56 ani (între 42-67 ani) în timp ce indicația pentru suprarenalectomia partială a fost reprezentată de sindromul Conn în patru cazuri, feocromocitom bilateral într-un caz şi respectiv tumori suprarenale nonfuncționale în două cazuri. Preoperator samplingul venei adrenale $\mathrm{s}^{-a}$ efectuat cu succes într-un singur caz. Testul pe bază de verde indocianin (ICG) şi respectiv ecografia intraoperatorie au fost utilizate în câte trei cazuri fiecare. Operatiile au fost realizate prin abord transperitoneal, laparoscopic (5) sau asistat robotic (2). Nu s-a înregistrat nici o conversie la chirurgie deschisă şi respectiv nici o suprarenalectomie totală.

Concluzii: chirurgia minim invazivă pare să fie o metodă sigură şi eficientă de efectuare a adrenalectomiilor parțiale. Mai mult decât atât, dezvoltarea noilor tehnologii de timpul sampling-ului de venă adrenală, a testului cu verde indocianin sau a ecografiei intraoperatorii par să crească fezabilitatea metodei precum şi numărul 
cazurilor ce ar putea beneficia de pe urmele acestei metode.

Cuvinte cheie: adrenalectomie parțială, abord minim invaziv, verde indocianin

\section{Abstract}

Background: Partial adrenalectomy has been widely performed in the last decades in order to diminish the number of patients who would become lifetime dependent of hormonal replacement.

Method: between 2016 and 2018 seven patients were submitted to minimally invasive partial adrenalectomy in Ponderas Academic Hospital.

Results: the median age at the time of surgery was 56 years (range $42-67$ years) while the indications for partial adrenalectomy (PA) were represented by Conn's syndrome in four cases, bilateral pheochromocytoma in one cases and nonfunctional adrenal tumors in two cases. Preoperatively successful adrenal vein sampling was performed in one case. The indocyanine green test (ICG) as well as intraoperative ultrasound were used each in three cases. The transperitoneal approach was used for PA in all patients, laparoscopic in five and robotic assisted in two patients. No conversion to open surgery or to total suprarenalectomy was encountered.

Conclusions: minimally invasive surgery seems to be a safe and effective method to perform partial adrenalectomy. Moreover, development of novel technologies such as adrenal vein sampling, indocyanine green test or intraoperative ultrasound seem to increase the feasibility of the method as well as the number of cases who could benefit from the type of approach.

Use of new technology?

Key words: partial adrenalectomy, minimally invasive approach, indocyanine green

\section{Introduction}

Since the year of 1992, when the first laparoscopic adrenalectomies (LA) have been reported (1) the minimally invasive approach was more often used and soon it became the standard of care in treating the pathology of the adrenal gland (2). Therefore, the method was able to demonstrate the benefits of the minimally invasive surgery (MIS) for these patients, and to achieve similar long-term outcomes when compared to open surgery $(3,4)$. Moreover, in the last decades, due to the increased expertise of using MIS, the evolution of imaging technologies, as well the progress of endocrinology and oncology, an increasing number of cases could benefit from a more conservative approach consisting of partial adrenalectomy $(5,6)$. Laparoscopic partial adrenalectomy (LPA) was initially performed in 1997 in a patient with bilateral adrenal adenomas, being considered at that moment as a more demanding procedure when compared to total adrenalectomy (7). However, in time, the concept of MIS partial adrenalectomy has proved its benefits and it was widely accepted in patients with benign or even metastatic adrenal pathology $(8,9)$, being considered in patients with previous history of contra-lateral total adrenalectomy and who may otherwise become lifetime dependent of hormonal replacement (10).

Soon after getting more experienced with the total LA technique (11) we have introduced LPA in our current practice. Over the last years, other technologies such as percutaneous adrenal veins catheterization, laparoscopic ultrasound (LUS), indocyanine green florescence (ICG) and robotic surgery were introduced in our current practice and they were applied for MIS partial adrenalectomies (MIS-PA).

The objective of the current study was to analyze the outcomes of laparoscopic and 
robotic partial adrenalectomy performed in our department within the last three years (2016-2019).

The aim of this paper is to report our recent experience in performing MIS-PA, considering the influence and the advantages of the above-mentioned technologies to the current surgical technique.

\section{Methods}

All the patients who underwent partial adrenalectomy in our institution between August 2016 and August 2019 were included into the current study. Data from the patients, the surgical and medical outcomes were retrospectively reviewed after obtaining IRB approval.

The preoperative workup included the evaluation of a multidisciplinary team (endocrinologist, cardiologist, anesthetist, surgeon) and CT scan in all the patients (Fig. 1).

In the patients with Conn syndrome adrenal vein sampling was considered to determine whether the hormonal over production is unilateral or bilateral especially when tumors are present in both glands. The central adrenal veins of the right and left glands were catheterized via a percutaneous femoral venous approach. Blood samples were assayed for aldosterone and cortisol at baseline and following corticotropin stimulation by continuous infusion of Synacthen (Tetracosactide, beta1-24corticotrophin), $250 \mathrm{ug} / 20 \mathrm{ml}$ saline, $1 \mathrm{ml} / \mathrm{min}$. Bilateral adrenal veins' aldosterone serum concentration were compare in-between and to the peripheral concentration, at baseline, 15, 20, 25, 40 and 50 minutes after stimulation. At least twice relative increase of the central levels was considered suggestive for aldosterone secreting adenoma.

The minimally invasive approach was considered for all the patients included in the study, the laparoscopic option being previously available while the robotic assisted partial adrenalectomy was introduced only in 2018 (DaVinci Xi).

The procedures were performed in Ponderas Academic Hospital and all the patients signed the informed consent which included the acceptance of the total adrenalectomy if intraoperatively will be decided so.

\section{Operative Technique}

MIS-PS were performed under general anesthesia with orotracheal intubation, and the patients were placed in lateral decubitus. Transperitoneal approach was preferred. The CO2 pneumoperitoneum induction was obtained by an initial access of a Veress needle. AirSeal ${ }^{\circledR}$ System (Conmed, US) was be preferred for gas insufflation. After placing the optical trocar at the level of the periumbilical area, two or three other trocars were placed
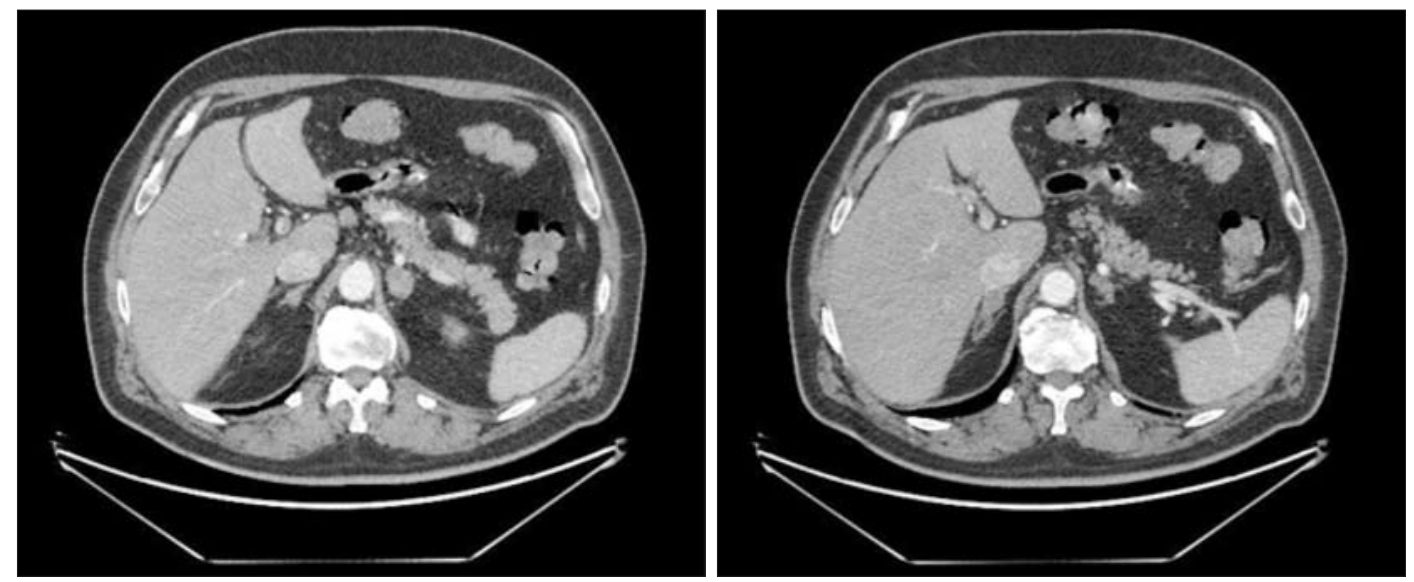

Figure 1. Computer tomography. Bilateral adrenal nodular hyperplasia 
under direct visualization, parallel and $5 \mathrm{~cm}$ below the ipsilateral costal margin, respecting the rules of triangulation. In the cases presenting a right adrenal tumor, a supplemental trocar in the epigastric area was always introduced for the $10 \mathrm{~mm}$ Cuschieri snake-like liver retractor (KARL-STORZ, Germany) (11). If the robotic approach was chosen, the $8 \mathrm{~mm}$ trocars were placed much lower form the costal margin, respecting at least $8 \mathrm{~cm}$ distance in-between, in order to minimize the risk of collision.

A 45 degrees telescope, double fenestrated forceps (Croce-Olmi, KARL-STORZ, Germany), a monopolar hook, scissors, bipolar energy devices and the harmonic ACE are necessary for LAP_PA. Similarly, a 30 endoscope, monopolar scissors, bipolar Maryland forceps and a Pro-Grasp are completing the set of instruments used for robotic assisted PA. The Fire-Fly function was used in all the robotic cases while the IMAGE 1S (Karl-Storz, Germany) or PINPOINT (Novadaq) near-infrared light (NIR) technology was used for the LAP-PA.

Using a lateral and posterior dissection, by applying our previously described modification of the adrenalectomy technique (11), an extended mobilization of the adrenal gland is achieved while all the vascular connections are maintained. The central, inferior and superior veins and arteries are identified. As both sides of the adrenal gland are exposed the nodule or the tumor might be evident or not. However, intraoperative sonography is always used in order to localize the tumor, to evaluate the entire adrenal parenchyma, to exclude the presence of other nodules and to help marking the resection's limit.

Furthermore, the proximity of the nodule to the vascular pedicles will dictate their safe preservation, and, as consequence, the extension of the partial resection.

The medial MIS-PA includes the resection of the medial and sometimes inferior adrenal pedicle while the remaining gland will lay on the superior branches (Fig. 2). As for the lateral MIS-PA, the central vein and artery are preserved while the superior and sometimes the inferior pedicles are clipped or sealed with energy devices. Stapling devices (Purple color, Tri-Stapling Technology, Covidien, Medtronic, US) were used to transect the adrenal in both types of MIS-PA. Care was taken to respect a safety margin of $3-5 \mathrm{~mm}$ from the tumor, following the US-guided sectioning line.

The central nodules may allow the preservation of the adrenal pedicles while the MIS-PS is more or less a tumor excision with safety margins. Monopolar energy, Bipolar diathermy (Ligasure Technology, Covidien, Medtronic, US) or Ultrasonic Shears (Harmonic ACE, Ethicon, US) are used for the purpose. Sometimes the inferior pedicle is divided.

Near-infrared light (NIR) technology with Indocyanine green (ICG) enhanced fluorescence was introduced in our practice in 2017. For MIS-PA, the ICG fluorescence confirms that the limit of the resection is within a vascularized aria. The investigation was used for medial and lateral MIS-PA, after dividing the respective vascular pedicles. Intravenous indocyanine green (ICG) solution ( $5 \mathrm{ml}$ of 2.5 $\mathrm{mg} / \mathrm{ml}$ ) is used and a carefully inspection the aspect of the adrenal gland is performed under NIR. The safety margin marked under US-guidance should be inside the well vascularized territory (Fig. $3 A, B$ ) The stapled line will be oriented accordingly.

The specimen is placed into an Endobag and is retrieved through an access port which is sometimes enlarged and further sutured by

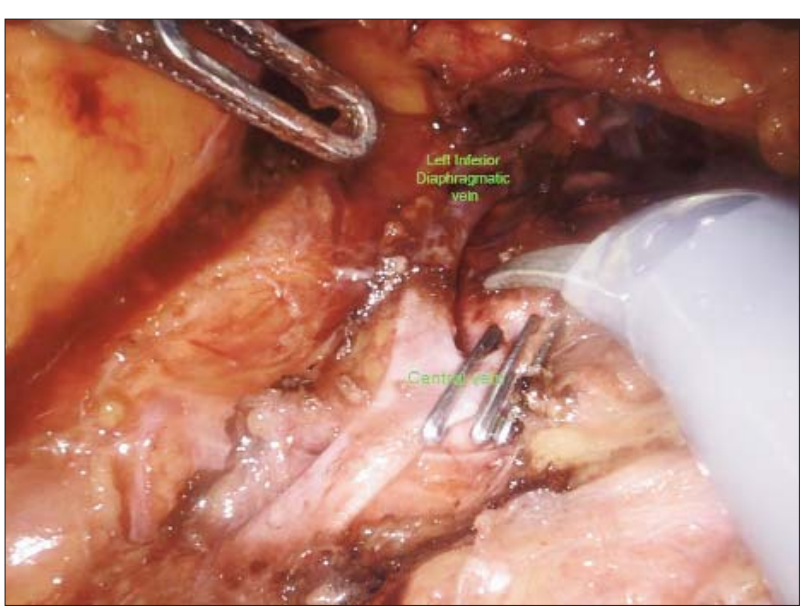

Figure 2. The left central vien is clipped at the confluence with inferior left diaphrafmatic vein 

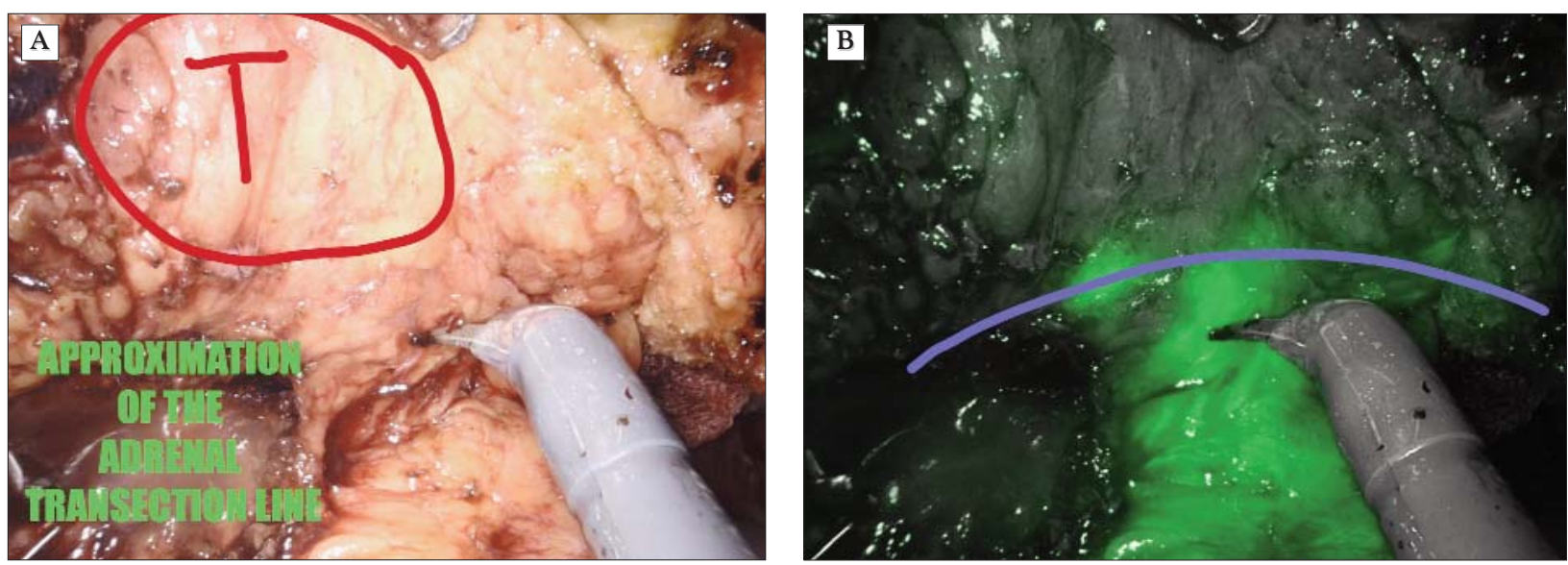

Figure 3. Robotic assisted partial adrenalectomy. At this stage the central vein is divided. Both pictures present the same perspective of the inferior aspect of the left gland. (A) Approximation of the transection line - relative to the tumor site (T) as it was confirmed by intraoperative ultrasound; (B) Approximation of the transection line - better oriented in FireFly Mode-NIR-ICG florescence

using a fascia closure device.

The entire stapled line is carefully evaluated after firing. Using NIR and ICG fluorescence the absence of the ischemic gaps should be demonstrated (Fig. 4 A, B).

ICG fluorescence was not used to evaluate the adrenal gland vascularization after central nodules' excision or PA as at least the central and superior pedicles are preserved. In these particular cases, ICG may demonstrate an isolated aria of non-perfusion corresponding to the nodule and helps guiding the excision.

A NIR inspection of the aria is mandatory
20 minutes from the initial ICG i.v. administration in order to evaluate the remaining adrenal venous drainage.

In the cases of poor vascularization of the adrenal stump or its' inadequate wash-out, exposing to the risk of congestion of the gland, total adrenalectomy may be considered.

In order to minimize the risk of postoperative bleeding, at the end of the MIS-PA, the blood pressure is routinely increased up to $30 \%$ relative to the preoperative levels, by using intravenous ephedrine. Intraoperatively hemostasis is then completed by using
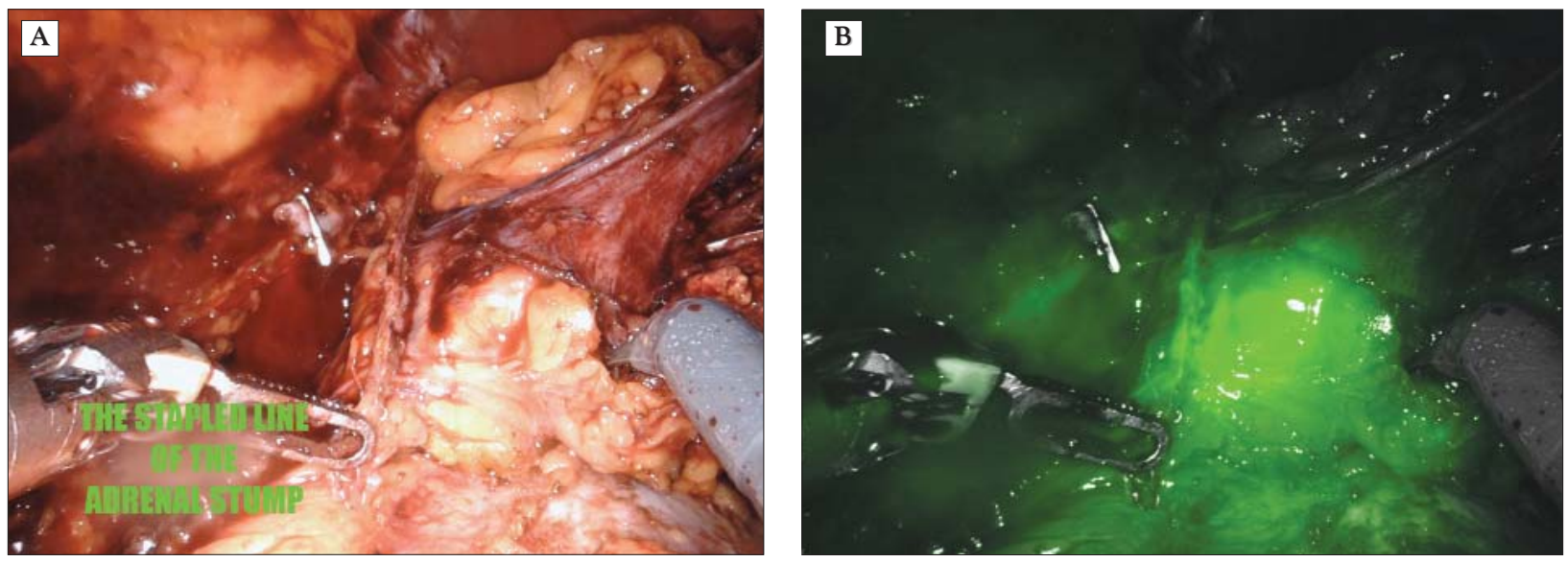

Figure 4. (A) Inspection of the stapled line on the adrenal stump; (B) - Inspection of the stapled line on the adrenal stump with NIR ( FireFly Technology - DaVinci Xi) 
monopolar, bipolar or argon beam coagulation devices as well by placing Titanium hemostatic clips on the bleeders.

A spiral drain is left in place for the next 24 hours. Careful evaluation of the multidisciplinary team is necessary after MIS-PA. The blood pressure is continuously monitored, and its normalization should be noted in Conn Syndrome and Pheochromocytoma patients. Clear liquid diet, anti-thrombotic prophylaxis with low molecular heparin and the early patient's mobilization are recommended from the first postoperative day (POD). The hospital discharge is expected in the POD 2 or 3 , after bowel movements are noted and the patient will be further followed up by endocrinologist.

The postoperative complications were encountered and classified according to DindoClavien scale (12).

\section{Statistical Analysis}

Descriptive statistics were used to summarize patient demographics and for a preliminary analysis of data. Comparisons were made using the Relative Risk (RR) and Fishers' Exact Test. The data analysis program used MedCalc.

\section{Results}

Seven patients, median age of 56 years (range $=$ 45-67 years) were submitted to MIS partial adrenalectomy within the analyzed interval. The indication for performing partial adrenalectomy were represented by Conn's syndrome in four cases, bilateral pheochromocytoma in one cases and nonfunctional adrenal tumors in two cases. Significant higher levels of Aldosterone were encountered after corticotropin stimulation, in adrenal vein sampling from the gland hosting the hormone over-productive adenoma in a $42 y$ old male patient with primary hyperaldosteronism and bilateral adrenal nodular hyperplasia. The Aldosterone level at baseline in inferior vena cava (IVC) was $79 \mathrm{ng} / \mathrm{ml}$ while 30' after Synacthen stimulation was 392 and $592 \mathrm{ng} / \mathrm{ml}$, from the right and left adrenal vein sampling, respectively.

In all cases a MIS transperitoneal approach was used, five cases being submitted to laparoscopic and two for robotic assisted PA Table 1.

The central adrenal vein was preserved in five cases for which lateral or central MIS-PA was decided. Medial PA was performed in two cases, one laparoscopic and one robotic assisted Table 2.

Stapling technology was used to transect the adrenal in five cases (three laparoscopic and two robotic assisted PA).

Near-infrared light (NIR) technology with Indocyanine green (ICG) enhanced fluorescence was used in 3 patients (one laparoscopic and two robotic assisted PA) Table 2. No total adrenalectomy and no conversion to open surgery were encountered within this series.

Table 1. Preoperative data of patients submitted to MIS partial adrenalectomy

\begin{tabular}{lcclcc}
\hline $\begin{array}{l}\text { Patient } \\
\text { No }\end{array}$ & Age & Gender & Diagnostic & $\begin{array}{c}\text { Adrenal vein } \\
\text { sampling }\end{array}$ & $\begin{array}{c}\text { Tumor diameter } \\
\text { (at CT scan) }\end{array}$ \\
\hline 1 & 58 & F & Nonfunctional tumor & No & $4 / 1 / 1.5 \mathrm{~cm}$ \\
\hline 2 & 51 & $\mathrm{~F}$ & $\begin{array}{l}\text { Nonfunctional tumor with } \\
\text { rapid one year growth }\end{array}$ & No & $3 / 1.5 / 2 \mathrm{~cm}$ \\
3 & 63 & M & Primary hyperaldosteronism & No & $1 / 2 / 1 \mathrm{~cm}$ \\
\hline 4 & 67 & F & Primary hyperaldosteronism & No & $2.5 / 3 / 2 \mathrm{~cm}$ \\
\hline 5 & 53 & M & Primary hyperaldosteronism & No & $1 / 2 / 1 \mathrm{~cm}$ \\
\hline 6 & 42 & M & $\begin{array}{l}\text { Primary hyperaldosteronism } \\
\text { and bilateral adrenal nodular hyperplasia }\end{array}$ & Yes & $1 / 0,5 / 1 \mathrm{~cm}$ \\
\hline 7 & 63 & M & $\begin{array}{l}\text { bilateral pheochromocytoma with previous } \\
\text { adrenalectomy }\end{array}$ & No & $4 / 3 / 2 \mathrm{~cm}$ \\
\hline
\end{tabular}


Table 2. Intraoperative and postoperative data of patients submitted to MIS partial adrenalectomy

\begin{tabular}{|c|c|c|c|c|c|c|c|c|c|}
\hline $\begin{array}{l}\text { Patient } \\
\text { No }\end{array}$ & Type of approach & ICG use & I0-US & PA-Type & $\begin{array}{c}\text { Histopathological } \\
\text { type }\end{array}$ & $\begin{array}{l}\mathrm{TS} \\
(\mathrm{min})\end{array}$ & $\begin{array}{l}\text { Blood loss } \\
\text { (ml) }\end{array}$ & $\begin{array}{l}\text { PO } \\
\text { compl. }\end{array}$ & HS \\
\hline 1 & Laparoscopic & No & No & central & nodular hyperplasia & 155 & 30 & No & 3 \\
\hline 2 & Laparoscopic & No & No & lateral & nodular hyperplasia & 100 & 70 & No & 3 \\
\hline 3 & Laparoscopic & No & Yes & lateral & Adenoma & 140 & 20 & No & 3 \\
\hline 4 & Laparoscopic & Yes & No & lateral & Adenoma & 100 & 30 & No & 3 \\
\hline 5 & Laparoscopic & No & No & Medial & Adenoma & 90 & 40 & No & 3 \\
\hline 6 & Robotic & Yes & Yes & Medial & Adenoma & 150 & 50 & No & 3 \\
\hline 7 & Robotic & Yes & Yes & lateral & pheochromocytoma & 180 & 100 & $\begin{array}{l}\text { Urinary tract } \\
\text { infection }\end{array}$ & 4 \\
\hline
\end{tabular}

LAP: Laparoscopic; IO-US: Intraoperative Ultrasound; TS: Time of Surgery; PO compl.: Postoperative Complications; HS: Hospital Stay

Intraoperatively hemostasis was achieved by using the diathermy or clips. No patient necessitated the use of argon beam coagulation.

The median length of the operative time was of 120 minutes (range $=90-180$ minutes) while the median blood loss was of $50 \mathrm{ml}$ (range $=20-100 \mathrm{ml}$ ). No significant blood loss was noted for laparoscopic and robotic assisted partial adrenalectomies.

Postoperatively, the drain was removed in the POD 1. A complicated postoperative course was encountered in one patient who developed a urinary tract infection (which was considered as a grade 2 Dindo-Clavien complication). The 30- and 90-days mortality was nil. The median hospital stay was 3.14 day (Table 2). In all cases the histopathological studies confirmed the presence of pathological tissue on the retrieved specimen as well as the presence of negative resection margins. In the meantime, in all cases a minimum volume of $20 \%$ of the initial adrenal gland was preserved in order to avoid the risk of adrenal insufficiency which might be further develop if contra-lateral adrenalectomy will be further needed.

Normal blood pressure was postoperatively demonstrated in all the Conn Syndrome and Pheochromocytoma patients after MIS-PA.

\section{Discussion}

The concept of partial adrenalectomy was initially proposed in 1997 in order to diminish the risk of lifetime hormonal administration and to reduce the risks of certain pathologies such as hypoandrogenism and osteoporosis which might develop if bilateral total adrenalectomy is performed (7). Moreover, in the absence of an adrenal preserving surgery, Addisionian crisis might be encountered in up to one third of cases submitted to bilateral adrenalectomy (13). In consequence, attention was focused on improving the technique of adrenal sparing procedures as well as on studying the long term outcomes after such procedures.

As for the indications of partial adrenalectomy, the procedure is commonly performed for patients presenting solitary adrenal glands, bilateral adrenal tumors or hereditary syndromes which predispose to the apparition of multiple adrenal masses; therefore, cases diagnosed with bilateral aldosterone producing adenomas, cortisol producing adenomas, pheochromocytomas and nonfunctional tumors seem to be the most commonly encountered candidates (14, 15). Moreover, cases presenting solitary, small tumors might be submitted to partial adrenalectomy in order to preserve the normal parenchyma and to diminish the potential risk of adrenal insufficiency if further contralateral gland surgery is needed $(6,7,16)$.

Actually, aldosterone producing adenomas represent the most commonly encountered indication for partial adrenalectomy. In cases presenting small peripheral tumors, partial adrenalectomy is a facile surgical procedure, 
with no need to interrupt the central vein, allowing in this way a proper function of the remnant parenchyma $(17,18)$.

However, in certain cases presenting small aldosterone producing adenomas adrenal vein sampling might be needed in order to confirm the diagnostic. The method has been successfully implemented in patients with Conn syndrome and consists of adrenal vein catheterization and sampling followed by determination of cortisol levels. The results are compared to those encountered in the peripheral blood stream, providing in this way a better identification of the parenchyma which is responsible for hormonal hypersecretion (19). In the study conducted by Deipolyi et al. the authors included 85 patients in whom central vein catheterize was tempted, 44 of them being further submitted to adrenalectomy. Among these 44 cases, successful venous sampling was performed in 31 cases; in 29 of the 31 cases the histopathological studies confirmed the presence of adrenocortical adenomas, demonstrating in this way the feasibility and efficacy of the method (19).

In cases diagnosed with pheochromocytomas, partial adrenalectomy with preservation of the adrenal cortex has been proposed with encouraging results. The method consists of removing the medullar area which is responsible for hormonal hypersecretion and preserving the peripheral area which presents normal hormonal function (20). However, attention should be paid to the fact that pneumoperitoneum and hypercapnia represent potential stimuli for catecholamine release and hypertensive crisis; moreover, the surgeon should be aware by the fact that laparoscopic partial adrenalectomy usually associates a higher degree of gland manipulation. Therefore, the risk of massive hormone release is higher. In these cases, a proper preparation with alpha- and beta-adrenergic blockade is mandatory. In order to provide a better identification of the demarcation line between the area which should be removed and the one which should be preserved, to minimize the manipulation of the gland and to diminish the length of surgery intraoperative ultrasound has been proposed with encouraging results (14).

In our experience, significant higher levels of Aldosterone were encountered after corticotropin stimulation, in adrenal vein sampling from the gland hosting the hormone over-productive nodule.

Similarly, to the total adrenalectomy, partial adrenalectomy can be performed in a transperitoneal or retroperitoneal manner using the standard laparoscopic approach or the robotic approach $(2,21,22)$. While the transperitoneal approach is associated with lower operative times since this approach is more familiar to the surgeon, it has also some disadvantages such as ileus, the risk of injury of adjacent organs and the adherence formation. The retroperitoneal approach offers a direct visualization of the adrenal gland and avoids the risk of intraperitoneal viscera injury (21); however, the working space is more limited and harder to be understood by the surgeon.

In our seven patients' series MIS transperitoneal approach was exclusively used, five cases being submitted to laparoscopic and two for robotic assisted partial adrenalectomy. The medial adrenal pedicle was identified in all the cases, but it was preserved only the five cases for which lateral or central MIS-PA was decided. The medial PA was performed in two cases, one laparoscopic and one robotic assisted.

As for the hemostasis control after partial adrenalectomy, different methods have been proposed, consisting of monopolar or bipolar coagulation, clip placement, fibrin glue placement or even vascular stapler placement (18). However, the latter method is not widely accepted due to the fact that the large diameter of the stapling device might increase the risk of removing too much healthy adrenal tissue (15).

In our series, the stapling technology was used in five out of the seven cases of MIS-PA. We have encountered no difficulties in using the device for the adrenal division, nor in the 
laparoscopic (3 patients) no in the robotic assisted PA (2 cases). We consider that the initial mobilization of the adrenal gland prior to the assessment of the transection line is mandatory and may support a facile use of stapling devices. Moreover, the safety margin of $3-5 \mathrm{~mm}$ from the tumor is better histologically evaluated on the specimen after the cold transection provided by the stapling technology as compared with the energy use.

As for the size of the staplers, we recommend the use of the higher ones (purple, green or black) in order to prevent the adrenal tissue laceration. However, if additional hemostasis will be necessary on the stapled line, titanium clips may be easily applied on.

In the other two cases, monopolar and bipolar technology was used for a central and a lateral PA, respectively. TACHOSIL ${ }^{\circledR}$ Fibrin Sealant Patch (Takeda, US) was applied in two cases.

One of the most important problems which should be taken in consideration after partial adrenalectomy is the one regarding the functionality of the remnant gland. This should refer to the preservation of the secretory function of the remnant parenchyma as well as to the risk of developing recurrent disease at this level. In one of the largest studies conducted on the theme of laparoscopic partial adrenalectomy for bilateral pheochromocytoma, 43 such procedures were performed in 33 patients; among these cases there was no postoperative dysfunction requiring long term steroid supplement. However, after a median follow-up interval of 36 months local recurrence was encountered in two cases which necessitated the totalization of the adrenalectomy (14). Moreover, the risk of recurrence seems to be higher in patients with inheritable syndromes, the reported rates of relapse ranging between $15 \%$ and $33 \%$ in this category of patients (23-25). In a similar study which was addressed this time to patients diagnosed with primary hyperaldosteronism, the authors included 63 patients submitted to total adrenalectomy and 29 patients submitted to partial adrenalectomy; among these cases the authors reported complete resolution of the symptoms in all cases submitted to total adrenalectomy and in 27 of the 29 cases submitted to partial adrenalectomy. In the remaining two cases, the persistent high plasmatic levels of aldosterone in association with persistent hypertension were explained by the presence of other microadenomas in the remnant adrenal parenchyma (26).

Therefore, in such cases, the decision of performing a partial adrenalectomy should be carefully analyzed. When it comes to the volume of the gland which should be preserved in order to avoid the risk of hormonal insufficiency if the contra-lateral gland is also removed, it seems that preserving a volume of $20 \%$ of parenchyma should be enough in order to offer hormonal protection (27).

In order to maximize the correct intraoperative identification of the interface between pathological and normal adrenal parenchyma, indocyanine green dye in association with near-infrared fluorescence imaging has been also proposed with promising results. In such cases $2-5 \mathrm{ml}$ solution of $2.5 \mathrm{mg} / \mathrm{ml}$ indocyanine green solution can be injected intravenously. Once the tracer is injected, the near infrared mode should be selected for the video-processor or robotic console (FireFly); most often the adrenal masses appear as hypo fluorescent lesions when compared to the surrounding normal adrenal parenchyma. The first report of the successful application of indocyanine green administration on adrenal surgery originates from Manny et al and included three such cases; in all cases the adrenal tumors proved to be hypo fluorescent and were successfully identified, the histopathological studies demonstrating the presence of pheochromocytoma, a follicular lymphoid hyperplasia and a lipoadenoma (28). However, the authors underlined the fact that the degree of capitation can be significantly influenced by the histopathological subtype of each lesion. In a more recent study, which was conducted on this theme, the authors included 100 cases submitted to adrenalectomy in which indocyanine green was administrated. Among these cases there were 29 patients with Cushing syndrome, 24 patients with pheochro- 
mocytoma, 23 cases with hyperaldosteronism, nine cases with non-secreting adrenocortical adenomas and 15 other histopathological subtypes. Among these cases the rates of hypo fluorescent lesions was of only $26 \%$, while the remaining $74 \%$ were hyperfluorescent; however the modification of fluorescence when compared to the surrounding parenchyma provided an excellent identification of the lesions (29).

In our series, near-infrared light (NIR) technology with Indocyanine green (ICG) enhanced fluorescence was used in 3 patients (one laparoscopic and two robotic assisted PA) in which the lesions were hypo-fluorescent. The purpose of ICG use in our series was not to identify the nodule but to confirm that the safety margin marked under US-guidance is inside the well vascularized territory. The stapled line or the energy transection line will be oriented accordingly. Furthermore, the entire stapled line was carefully evaluated for ischemic gaps, using NIR and ICG fluorescence. We believe that a NIR inspection of the aria is mandatory 20 minutes from the initial ICG i.v. administration in order to evaluate the remaining adrenal venous drainage. In the cases of poor vascularization of the adrenal stump or its' inadequate wash-out, exposing to the risk of congestion of the gland, total adrenalectomy may be considered.

By this approach the adrenal stump function can be intraoperatively evaluated and not by a postoperative computed tomography which may revealed or not a normal blood supply for the remaining adrenal tissue (15).

Once the benefits of laparoscopic partial adrenalectomy have been widely demonstrated, certain authors went further and studied whether the robotic approach might improve the outcomes. Using the da Vinci surgical system provides an increased, three dimensional view when compared to standard laparoscopy, providing a better chance to identify and preserve the vascular supply of the remnant adrenal gland as well as to identify the demarcation line between normal and pathological adrenal parenchyma (10). Moreover, it seems that significant differences in terms of perioperative out- comes can be also encountered depending on which type of robotic platform is used. An extremely interesting study conducted on this issue in Nashville, United States of America has been recently published in 2019; the study included 85 patients submitted to robotic surgery: 25 patients were submitted to surgery by using the $\mathrm{Xi}$ model while the remaining 60 cases were submitted to surgery by using the Si model. The authors demonstrated significantly lower anesthesia time, surgery time and docking time for the $\mathrm{Xi}$ group of patients as well as significantly lower costs for the consumables. In the meantime, no significant difference has been reported in terms of hospital in stay, diameter of the tumor or estimated blood loss between the two groups. Therefore, da Vinci Xi which represents the fourth generation platform and which was released in the year 2014 seem to provide multiple benefits when compared to the similar Si system, improving the perioperative outcomes of patients submitted to robotic adrenalectomy (30).

Our robotic assisted PA series is very limited and there was no significant difference between the outcomes of these approach and the laparoscopic one. However, the quality of the tissue visualization, the accuracy of the dissection and the facile sequential adrenal tissue ICG evaluation in normal and NIR (FireFly) mode may be considered important technical advantages for the robotic assisted PA.

Besides its limitations (small sample size and the its retrospective nature) the present study clearly demonstrated very good outcomes for the laparoscopic and robotic partial adrenalectomy. While underlining the significant influence and the advantages of the new technologies to the current surgical technique.

\section{Conclusion}

Laparoscopic partial adrenalectomy seems to be a safe and effective method in order to provide complete removal of small adrenal lesions, as well as preservation of normal glandular parenchyma. In this way the 
method prevents the risk of acute adrenal insufficiency which might develop if bilateral adrenal resection is needed. Recent development in the field of technique such as adrenal adrenal vein sampling and indocyanine green utility seem to increase the rates of successful identification of small lesions and adrenal preservation of normal parenchyma. Moreover, utilization of da Vinci robot also seems to improve the outcomes of these patients by providing a magnified, threedimensional view, encouraging results being reported so far.

\section{Conflict of Interest}

The authors declare no conflicts of interests.

\section{References}

1. Gagner M, Lacroix A, Bolte E. Laparoscopic adrenalectomy in Cushing's syndrome and pheochromocytoma. N Engl J Med. 1992; 327(14):1033.

2. Conzo G, Tartaglia E, Gambardella C, Esposito D, Sciascia V, Mauriello C, et al. Minimally invasive approach for adrenal lesions: Systematic review of laparoscopic versus retroperitoneoscopic adrenalectomy and assessment of risk factors for complications. Int J Surg. 2016;28 Suppl 1:S118-23.

3. Brunt LM, Doherty GM, Norton JA, Soper NJ, Quasebarth MA, Moley JF. Laparoscopic adrenalectomy compared to open adrenalectomy for benign adrenal neoplasms. J Am Coll Surg. 1996; 183(1):1-10.

4. Thompson GB, Grant CS, van Heerden JA, Schlinkert RT, Young WF, Jr., Farley DR, et al. Laparoscopic versus open posterior adrenalectomy: a case-control study of 100 patients. Surgery. 1997;122(6):1132-6.

5. Heniford BT, lannitti DA, Hale J, Gagner M. The role of intraoperative ultrasonography during laparoscopic adrenalectomy. Surgery. 1997;122(6):1068-73.

6. Imai T, Tanaka Y, Kikumori T, Ohiwa M, Matsuura N, Mase T, et al. Laparoscopic partial adrenalectomy. Surg Endosc. 1999;13(4): 343-5.

7. Janetschek G, Lhotta K, Gasser R, Finkenstedt G, Jaschke W, Bartsch G. Adrenal-sparing laparoscopic surgery for aldosteroneproducing adenoma. JEndourol. 1997;11(2):145-8.

8. Kumar A, Hyams ES, Stifelman MD. Robot-assisted partial adrenalectomy for isolated adrenal metastasis. J Endourol. 2009;23(4): 651-4.

9. Kaye DR, Storey BB, Pacak K, Pinto PA, Linehan WM, Bratslavsky G. Partial adrenalectomy: underused first line therapy for small adrenal tumors. J Urol. 2010;184(1):18-25.

10. Yates J, Uberoi J, Munver R. Robot-assisted laparoscopic partial adrenalectomy: a case report and review of the literature. JRobotSurg. 2010;4(3):149-54.

11. Copaescu C. Laparoscopic suprarenalectomy. Chirurgia (Bucur). 2007;102(2):205-8.
12. Clavien PA, Barkun J, de Oliveira ML, Vauthey JN, Dindo D, Schulick $\mathrm{RD}$, et al. The Clavien-Dindo classification of surgical complications: five-year experience. Ann Surg. 2009;250(2):187-96.

13. Lucon AM, Mendonca BB, Domenice S, Chambo JL, Wajchemberg BL, Arap S. Adrenal autografts following bilateral adrenalectomy. J Urol. 1993;149(5):977-9.

14. Janetschek G, Finkenstedt G, Gasser R, Waibel UG, Peschel R, Bartsch $G$, et al. Laparoscopic surgery for pheochromocytoma: adrenalectomy, partial resection, excision of paragangliomas. JUrol. 1998;160(2):330-4

15. Jeschke K, Janetschek G, Peschel R, Schellander L, Bartsch G, Henning K. Laparoscopic partial adrenalectomy in patients with aldosterone-producing adenomas: indications, technique, and results. Urology. 2003;61(1):69-72.

16. Miron A, Giulea C, Nadragea M, Enciu O. Laparoscopic Partial Adrenalectomy. Chirurgia (Bucur). 2017;112(1):77-81.

17. Cavallaro G, Polistena A, D'Ermo G, Letizia C, De Toma G. Partial adrenalectomy: when, where, and how? Considerations on technical aspect and indications to surgery. European Surgery. 2012;44(3):150-4.

18. Silvinato A, Bernardo WM, Branco AW. Total and partial laparoscopic adrenalectomy. Rev Assoc Med Bras (1992). 2019;65(5): 578-85.

19. Deipolyi AR, Bailin A, Wicky S, Alansari S, Oklu R. Adrenal Vein Sampling for Conn's Syndrome: Diagnosis and Clinical Outcomes. Diagnostics(Basel). 2015;5(2):254-71.

20. de Graaf JS, Lips CJ, Rutter JE, van Vroonhoven TJ. Subtotal adrenalectomy for phaeochromocytoma in multiple endocrine neoplasia type 2A. EurJSurg. 1999;165(6):535-8.

21. Walz MK, Peitgen K, Diesing D, Petersenn S, Janssen OE, Philipp T, et al. Partial versus total adrenalectomy by the posterior retroperitoneoscopic approach: early and long-term results of 325 consecutive procedures in primary adrenal neoplasias. World $\mathrm{J}$ Surg. 2004;28(12):1323-9.

22. Nomine-Criqui C, Germain A, Ayav A, Bresler L, Brunaud L. Robotassisted adrenalectomy: indications and drawbacks. Updates Surg. 2017;69(2):127-33.

23. Neumann HP, Reincke M, Bender BU, Elsner R, Janetschek G. Preserved adrenocortical function after laparoscopic bilateral adrenal sparing surgery for hereditary pheochromocytoma. J Clin Endocrinol Metab. 1999;84(8):2608-10.

24. Pacak K, Linehan WM, Eisenhofer G, Walther MM, Goldstein DS. Recent advances in genetics, diagnosis, localization, and treatment of pheochromocytoma. AnnInternMed. 2001;134(4):315-29.

25. Walther MM, Herring J, Choyke PL, Linehan WM. Laparoscopic partial adrenalectomy in patients with hereditary forms of pheochromocytoma. J Urol. 2000;164(1):14-7.

26. Ishidoya S, Ito A, Sakai K, Satoh M, Chiba Y, Sato F, et al. Laparoscopic partial versus total adrenalectomy for aldosterone producing adenoma. J Urol. 2005;174(1):40-3

27. Nakada T, Kubota $Y$, Sasagawa I, Yagisawa T, Watanabe M, Ishigooka M. Therapeutic outcome of primary aldosteronism: adrenalectomy versus enucleation of aldosterone-producing adenoma. J Urol. 1995;153(6):1775-80.

28. Manny TB, Pompeo AS, Hemal AK. Robotic partial adrenalectomy using indocyanine green dye with near-infrared imaging: the initial clinical experience. Urology. 2013;82(3):738-42.

29. Kahramangil B, Kose E, Berber E. Characterization of fluorescence patterns exhibited by different adrenal tumors: Determining the indications for indocyanine green use in adrenalectomy. Surgery. 2018;164(5):972-7.

30. Feng Z, Feng MP, Feng DP, Solorzano CC. Robotic-assisted adrenalectomy using da Vinci Xi vs. Si: are there differences? J Robot Surg. 2019 Jul 4. [Epub ahead of print] 